\title{
Further New Highly Oxidative Cembranoids from the Hainan Soft Coral Sarcophyton trocheliophorum
}

\author{
Wen-Ting Chen $\cdot$ Lin-Fu Liang $\cdot$ Xu-Wen Li $\cdot$ \\ Wei Xiao · Yue-Wei Guo
}

Received: 7 December 2015/ Accepted: 18 January 2016/Published online: 15 March 2016

(C) The Author(s) 2016. This article is published with open access at Springerlink.com

\begin{abstract}
Three new highly oxidative cembranoids, sarcophytrols D-F (1-3), were obtained from the South China Sea soft coral Sarcophyton trocheliophorum, along with two known related ones (4 and $\mathbf{5})$. Their structures were elucidated by extensive spectroscopic analyses and by comparison with literature data. The discovery of these new secondary metabolites enriched the family of cembranoids deduced from the title animal.
\end{abstract}

Graphical Abstract

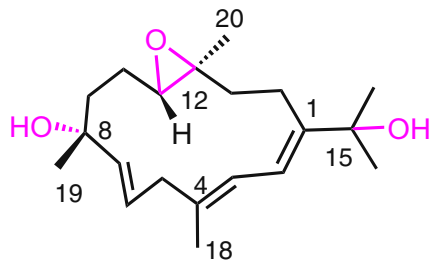

1

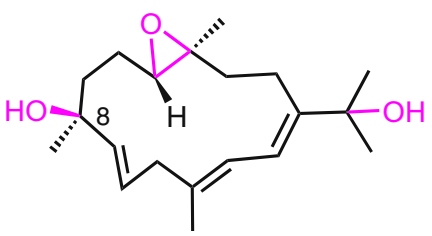

2

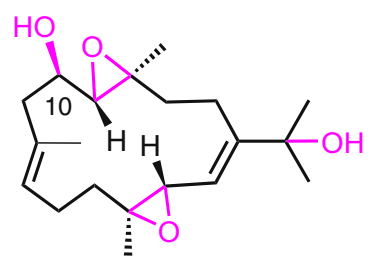

3

Keywords Soft coral $\cdot$ Sarcophyton trocheliophorum $\cdot$ Cembranoids $\cdot$ Sarcophytrol $\cdot$ Structure elucidation

Wen-Ting Chen and Lin-Fu Liang have contributed equally.

W.-T. Chen · L.-F. Liang · X.-W. Li · Y.-W. Guo $(\bowtie)$ State Key Laboratory of Drug Research, Shanghai Institute of Materia Medica, Chinese Academy of Sciences, $555 \mathrm{Zu}$ Chong Zhi Road, Zhang Jiang High-Tech Park, Shanghai 201203, People's Republic of China

e-mail:ywguo@mail.shcnc.ac.cn; ywguo@simm.ac.cn

L.-F. Liang

College of Material Science and Engineering, Central South University of Forestry and Technology, 498 South Shaoshan Road, Changsha 410004, People's Republic of China

W. Xiao $(\bowtie)$

Jiangsu Kanion Pharmaceutical Co., Ltd., Lianyungang 222001, People's Republic of China

e-mail: wzhzh-nj@163.com

\section{Introduction}

Soft corals (phylum Cnidaria, class Anthozoa, subclass Octocorallia, order Alcyonacea) often equal or exceed the total coverage of scleractinian corals in coral reef ecosystems [1-4]. The family Alcyoniidae within the order Alcyonacea contains the productive genus Sarcophyton [5, 6]. Till now, nearly 16 species of soft corals of the genus Sarcophyton, from various geographical areas, have been chemically investigated, being reported to comprise diverse diterpenes with different skeletons (cembrane, sarsolenane, capnosane, etc.) [5-9], biscembranoids [10-12], polyhydroxylated sterols [13, 14], and other related metabolites $[15,16]$. 
Sarcophyton species are prolific in the South China Sea. In the course of our search for bioactive substances from Chinese marine organisms, Sarcophyton trocheliophorum of the coast of Yalong Bay, Hainan Province, has been collected and chemically investigated, which were found to encompass numerous cembranoids with a variety of oxidation and cyclization patterns, including two unprecedented structures, methyl sarcotroates A and B [7-9, 12, 17]. In addition, many of them exhibited significant inhibitory activities against human PTP1B enzyme [7, 8, 17]. Recently, in order to find more chemically appealing and biologically active cembrane-based metabolites, $S$. trocheliophorum was re-collected from the same location while in a different growing period, and a further chemical investigation yielded three new highly oxidative compounds named sarcophytrols D-F (1-3), along with two known ones (4 and 5). Details of the isolation, structure elucidation and biological study of these secondary metabolites are reported herein.

\section{Results and discussion}

Samples of S. trocheliophorum (400 g, dry weight) were extracted exhaustively with acetone, and the extract was partitioned between $\mathrm{H}_{2} \mathrm{O}$ and $\mathrm{Et}_{2} \mathrm{O}$. The $\mathrm{Et}_{2} \mathrm{O}$ soluble fraction was subjected to silica gel chromatography (light petroleum ether/acetone gradient). The lower polar fractions were subsequently purified on repeated column chromatography (silica gel, Sephadex LH-20, reversed phase- $\mathrm{C}_{18}$ silica gel and semi preparative-HPLC) to afford five pure metabolites, compounds $\mathbf{1 - 5}$. A preliminary NMR analysis revealed that all the new molecules shared the same cembrane skeleton. Among them, two known compounds were readily identified as 11,12-epoxy-1(E),3(E), 7(E)-cembratrien-15-ol (4) [18] and sinugibberol (5) [19] by comparison of their spectral data and $[\alpha]_{D}$ values with those reported in the literature.

Sarcophytrol D (1) was obtained as colorless oil. The molecular formula was established as $\mathrm{C}_{20} \mathrm{H}_{30} \mathrm{O}_{3}$ by HRESIMS $\left(m / z 343.2248[\mathrm{M}+\mathrm{Na}]^{+}\right)$, sixteen mass units more than that of compound 4 [18]. In fact, their NMR spectra were similar, except for signals appeared in the downfield area. Differed from 4, the ${ }^{1} \mathrm{H}$ and ${ }^{13} \mathrm{C}$ NMR (Tables 1 and 2) data of $\mathbf{1}$ showed the presence of a trans-disubstituted double bond $\left(\delta_{\mathrm{H}} 5.75, \mathrm{~d}, J=15.7 \mathrm{~Hz} ; \delta_{\mathrm{H}} 5.68\right.$, ddd, $J=15.7,7.4,5.4 \mathrm{~Hz}$ ). In its ${ }^{1} \mathrm{H}-{ }^{1} \mathrm{H}$ COSY, the cross-peaks between $\mathrm{H}-5\left(\delta_{\mathrm{H}} 2.83,2.75\right)$ and $\mathrm{H}-6\left(\delta_{\mathrm{H}} 5.68\right)$, between H-6 and H-7 $\left(\delta_{\mathrm{H}} 5.75\right)$ indicated the linkage of C-5 to the trans-double bond. Furthermore, HMBC correlations from Me-19 $\left(\delta_{\mathrm{H}} 1.40\right)$ to $\mathrm{C}-7\left(\delta_{\mathrm{C}} 140.4\right)$ and from Me-18 $\left(\delta_{\mathrm{H}}\right.$ 1.78) to $\mathrm{C}-5\left(\delta_{\mathrm{C}} 41.47\right)$ confirmed the position of the double bond. In addition, Me-19 of compound 1 has been upfield shifted (from $\delta_{\mathrm{H}} 1.67$ in 4 to 1.40 in 1). Based on these NMR and MS variations, the hydroxylation at C-8 accompanying the double-bond migration from $\Delta^{7(8)}$ to $\Delta^{6(7)}$ in the structure of 1 were supported. Assignments of ${ }^{1} \mathrm{H}$ and ${ }^{13} \mathrm{C}$ NMR signals of $\mathbf{1}$ were made by the application of detailed 2D NMR analysis.

As for the relative configuration of compound $\mathbf{1}$, according to the ROESY correlations between $\mathrm{H}-2\left(\delta_{\mathrm{H}}\right.$ 6.30)/Me-17 $\left(\delta_{\mathrm{H}} 1.36\right), \mathrm{H}-2 / \mathrm{Me}-18\left(\delta_{\mathrm{H}} 1.78\right)$ and $\mathrm{H}-3\left(\delta_{\mathrm{H}}\right.$ 5.86)/H-14b ( $\delta_{\mathrm{H}}$ 2.22) (Fig. 1), the olefinic geometries were assigned to $1 E$ and $3 E$. The ${ }^{13} \mathrm{C}$ NMR chemical shift of Me-20 $\left(\delta_{\mathrm{C}}<20 \mathrm{ppm}\right)$ and the absence of the ROESY correlations of $\mathrm{H}-11\left(\delta_{\mathrm{H}} 3.08\right) / \mathrm{Me}-20\left(\delta_{\mathrm{H}} 1.25\right)$ indicated the trans-configuration of the epoxy group at C-11/C-12 in 1, which was the same as that in 4. Additional ROESY interactions of $\mathrm{H}-11 / \mathrm{H}-7, \mathrm{H}-7 / \mathrm{H}-9 \mathrm{~b}\left(\delta_{\mathrm{H}} 1.70\right), \mathrm{H}-9 \mathrm{~b} / \mathrm{H}-11$ suggested these three protons were co-facial, assigned tentatively as $\beta$-orientation. Thus, Me-19 was accordingly $\beta$-oriented due to the diagnostic cross-peak of Me-19 $\left(\delta_{\mathrm{H}}\right.$ 1.40) with $\mathrm{H}-7$, allowing the determination of the structure of 1 as showed in Fig. 2, which was the $\Delta^{6(7)}-8 \alpha$-hydroxyl derivative of $\mathbf{4}$.

Sarcophytrol E (2) was also obtained as colorless oil. The molecular formula, $\mathrm{C}_{20} \mathrm{H}_{30} \mathrm{O}_{3}$, established by HRESIMS $(\mathrm{m} /$ $z 343.2243\left[\mathrm{M}+\mathrm{Na}^{+}\right.$), was identical to that of $\mathbf{1}$. A detailed 2D NMR analysis of 2 and careful comparison with the NMR data of 1 (Tables 1 and 2) revealed that their structures were almost the same. In fact, the only differences between $\mathbf{2}$ and $\mathbf{1}$ were the C-19 signal downfield shifted in the ${ }^{13} \mathrm{C} N M R$ spetrum $\left(\delta_{\mathrm{C}} 28.8\right.$ in 1 and $\delta_{\mathrm{C}} 31.3$ in 2), while the C-6 and C-9 signals upfield shifted $\left(\delta_{\mathrm{C}} 125.0,40.1\right.$ in 1 and $\delta_{\mathrm{C}} 123.6,38.9$ in 2 , respectively). The observed differences can be rationalized when the two compounds are C-8 epimers, which was confirmed by the ROESY interaction of H-6 $\left(\delta_{\mathrm{H}}\right.$ 5.81)/Me-19 $\left(\delta_{\mathrm{H}} 1.36\right)$ (Fig. 3). Since the hydroxyl group at $\mathrm{C}-8$ of 1 was $\alpha$-oriented, the opposite configuration at this center is therefore tentatively suggested for 2 .

The HRESIMS of sarcophytrol F (3) established the molecular formula $\mathrm{C}_{20} \mathrm{H}_{32} \mathrm{O}_{4}\left(\mathrm{~m} / \mathrm{z} 359.2188[\mathrm{M}+\mathrm{Na}]^{+}\right)$, 16 mass units more than that of sinugibberol (5) [19]. The ${ }^{1} \mathrm{H}$ and ${ }^{13} \mathrm{C}$ NMR data of $\mathbf{3}$ showed great similarity as those of 5 (Tables 1 and 2), some minor differences were observed in relation to the functional group. The presence of a secondary hydroxyl group in the molecule was readily recognized by a signal resonating at $\delta_{\mathrm{H}} 3.70(1 \mathrm{H}$, ddd, $J=8.7,7.7,4.0 \mathrm{~Hz}$ ) in its ${ }^{1} \mathrm{H} \mathrm{NMR}$ spectrum, and by a carbon signal at $\delta_{\mathrm{C}} 69.1(\mathrm{CH})$ in the ${ }^{13} \mathrm{C}$ NMR and DEPT spectra. The oxygenated methine proton was secured at C-10 by a COSY cross-peak between $\mathrm{H}-9\left(\delta_{\mathrm{H}} 2.44,2.30\right)$ and $\mathrm{H}-11\left(\delta_{\mathrm{H}} 3.57\right)$, and the HMBC correlations with C-8, C-9 and C-11 (Fig. 4). Due to the presence of the $10-\mathrm{OH}$, 
Table $1{ }^{1} \mathrm{H}$ NMR data $\left[\delta_{\mathrm{H}}\right.$ (mult., $J$ in Hz)] for compounds $\mathbf{1}-\mathbf{3}^{\mathrm{a}}$

\begin{tabular}{|c|c|c|c|}
\hline No. & 1 & 2 & 3 \\
\hline 2 & $6.30, \mathrm{~d},(11.4)$ & $6.32, \mathrm{~d}(11.3)$ & $5.34, \mathrm{~d}(6.4)$ \\
\hline 3 & $5.86, \mathrm{~d},(11.4)$ & $5.73, \mathrm{~d}(11.3)$ & $3.36, \mathrm{~d}(6.4)$ \\
\hline \multirow[t]{2}{*}{5} & $2.83, \mathrm{dd}(17.7,7.4)$ & 2.84, dd $(17.7,9.2)$ & $2.07, \mathrm{~m}$ \\
\hline & $2.75, \mathrm{dd}(17.7,5.4)$ & $2.78, \mathrm{dd}(17.7,4.6)$ & $1.61, \mathrm{~m}$ \\
\hline \multirow[t]{2}{*}{6} & 5.68, ddd $(15.7,7.4,5.4)$ & 5.81 , ddd $(15.6,9.2,4.6)$ & $2.22, \mathrm{~m}$ \\
\hline & & & $2.02, \mathrm{~m}$ \\
\hline 7 & $5.75, \mathrm{~d}(15.7)$ & $5.71, \mathrm{dd}(15.6,1.5)$ & $5.26, \mathrm{t}(5.8)$ \\
\hline \multirow[t]{2}{*}{9} & 2.00, ddd $(12.7,8.3,1.9)$ & $1.96, \mathrm{~m}$ & $2.44, \mathrm{dd}(6.3,13.7)$ \\
\hline & 1.70, ddd $(12.7,11.5,9.1)$ & $1.79, \mathrm{~m}$ & $2.30, \mathrm{dd}(3.4,13.7)$ \\
\hline \multirow[t]{2}{*}{10} & $1.92, \mathrm{~m}$ & $2.03, \mathrm{~m}$ & 3.70, ddd $(8.7,7.7,4.0)$ \\
\hline & $1.63, \mathrm{~m}$ & $1.52, \mathrm{~m}$ & \\
\hline 11 & $3.08, \mathrm{t}(6.2)$ & $3.22, \mathrm{dd}(7.4,4.3)$ & $2.90, \mathrm{~d}(8.7)$ \\
\hline \multirow[t]{2}{*}{13} & $1.94, \mathrm{~m}$ & $2.22, \mathrm{~m}$ & $2.11, \mathrm{~m}$ \\
\hline & $1.10, \mathrm{dd}(12.9,6.6)$ & $0.79, \mathrm{~m}$ & $1.44, \mathrm{dd}(2.3,12.5)$ \\
\hline \multirow[t]{2}{*}{14} & 2.33, ddd $(13.2,11.1,6.8)$ & $2.22, \mathrm{~m}$ & $2.21, \mathrm{~m}$ \\
\hline & $2.22, \mathrm{dd}(11.1,3.0)$ & & $2.16, \mathrm{~m}$ \\
\hline 16 & $1.36, \mathrm{~s}$ & $1.36, \mathrm{~s}$ & $1.36, \mathrm{~s}$ \\
\hline 17 & $1.36, \mathrm{~s}$ & $1.36, \mathrm{~s}$ & $1.36, \mathrm{~s}$ \\
\hline 18 & $1.78, \mathrm{~s}$ & $1.78, \mathrm{~s}$ & $1.25, \mathrm{~s}$ \\
\hline 19 & $1.40, \mathrm{~s}$ & $1.36, \mathrm{~s}$ & $1.76, \mathrm{~s}$ \\
\hline 20 & $1.25, \mathrm{~s}$ & $1.24, \mathrm{~s}$ & $1.30, \mathrm{~s}$ \\
\hline
\end{tabular}

${ }^{\text {a }}$ Bruker-DRX-500 spectrometer $(500 \mathrm{MHz})$ in $\mathrm{CDCl}_{3}$; chemical shifts (ppm) referred to $\mathrm{CHCl}_{3}\left(\delta_{\mathrm{H}} 7.26\right)$; assignments were deduced from analysis of 1D and 2D NMR spectra

${ }^{13} \mathrm{C}$ NMR chemical shifts of C-9 to C-12 were all reasonably downfield shifted with respect to those of $\mathbf{5}$.

Finally, the relative configuration of $\mathbf{3}$ was determined by ROESY experiment and by comparison of the NMR data with 5 (Fig. 4). The ${ }^{13} \mathrm{C}$ NMR chemical shift of Me-18 and Me-20 $\left(\delta_{\mathrm{C}}<20 \mathrm{ppm}\right)$ and the absence of ROESY correlations of Me-18 $\left(\delta_{\mathrm{H}} 1.25\right) / \mathrm{H}-3\left(\delta_{\mathrm{H}} 3.36\right)$, and Me-20 $\left(\delta_{\mathrm{H}} 1.30\right) / \mathrm{H}-11\left(\delta_{\mathrm{H}} 2.90\right)$, indicated the trans-configurations of these two epoxy groups at C-3/C-4 and C-11/C-12 in 3, which were the same as those in $\mathbf{5}$. The similar ${ }^{13} \mathrm{C}$ NMR data of C-3 and C-4 in $\mathbf{3}$ and $\mathbf{5}$ further confirmed the same stereochemistry of this epoxy group. Furthermore, the ROESY correlations of $\mathrm{H}-11 / \mathrm{H}-13 \mathrm{a}\left(\delta_{\mathrm{H}} 1.44\right), \mathrm{H}-3 / \mathrm{H}-13 \mathrm{a}$, suggested that $\mathrm{H}-11$ and $\mathrm{H}-3$ were co-facial, leading to the determination of the relative configurations at $\mathrm{C}-11$ and $\mathrm{C}-12$ where the other epoxy group resided on. In addition, the ROESY correlations of $\mathrm{H}-10 / \mathrm{Me}-20$ indicated that 10-OH and H-11 were co-facial. Due to the scarcity of material, the modified Mosher's method could not be able to apply for the determination of the absolute configuration in C-10 position in $\mathbf{3}$ at this moment. Thus the structure of sarcophytrol F (3) was tentatively determined as 10-hydroxyl derivative of $\mathbf{5}$.

All the compounds were tested for the cytotoxic activities and inhibitory activities against human protein tyrosine phosphatase 1B (PTP1B), a key target for the treatment of type-II diabetes and obesity [20]. Unfortunately, none of them showed inhibitory effects toward the above bioassays. Further study should be conducted to understand the real biological/ecological role of these metabolites in the life cycle of the animal, as well as to carry out other biological evaluations such as antioxidant, anti-inflammatory, anti-fouling activities, etc.

\section{Experimental Section}

\subsection{General Experimental Procedures}

Optical rotations were measured on a Perkin-Elmer 341 polarimeter. HRESIMS spectra were recorded on a WatersMicromass Q-TOF Ultima Global electrospray mass spectrometer. NMR spectra were measured on a BrukerDRX-500 spectrometer with the residual $\mathrm{CHCl}_{3}\left(\delta_{\mathrm{H}}\right.$ $\left.7.26 \mathrm{ppm}, \delta_{\mathrm{C}} 77.0 \mathrm{ppm}\right)$ as internal standard. Chemical shifts are expressed in $\delta$ (ppm) and coupling constants $(J)$ in $\mathrm{Hz} .{ }^{1} \mathrm{H}$ and ${ }^{13} \mathrm{C}$ NMR assignments were supported by ${ }^{1} \mathrm{H}-{ }^{1} \mathrm{H}$ COSY, HSQC, and HMBC experiments. Commercial silica gel (Qing Dao Hai Yang Chemical Group Co., 200-300 and 400-600 mesh), $C_{18}$ reversed-phase silica gel 
Table $2{ }^{13} \mathrm{C}$ NMR data $\left(\delta_{\mathrm{C}}\right.$, mult.) for compounds $\mathbf{1}-\mathbf{3}^{\mathrm{a}}$ and $\mathbf{5}^{\mathrm{b}}$

\begin{tabular}{lrrrr}
\hline No. & \multicolumn{1}{l}{ 1 } & \multicolumn{1}{l}{3} & \multicolumn{1}{c}{5} \\
\hline 1 & $147.6, \mathrm{~s}$ & $147.3, \mathrm{~s}$ & $150.9, \mathrm{~s}$ & $150.9, \mathrm{~s}$ \\
2 & $117.4, \mathrm{~d}$ & $117.6, \mathrm{~d}$ & $121.0, \mathrm{~d}$ & $125.8, \mathrm{~d}$ \\
3 & $119.8, \mathrm{~d}$ & $119.6, \mathrm{~d}$ & $58.7, \mathrm{~d}$ & $59.3, \mathrm{~d}$ \\
4 & $138.2, \mathrm{~s}$ & $138.4, \mathrm{~s}$ & $61.9, \mathrm{~s}$ & $61.7, \mathrm{~s}$ \\
5 & $41.4, \mathrm{t}$ & $41.4, \mathrm{t}$ & $37.3, \mathrm{t}$ & $36.8, \mathrm{t}$ \\
6 & $125.0, \mathrm{~d}$ & $123.6, \mathrm{~d}$ & $22.1, \mathrm{t}$ & $22.3, \mathrm{t}$ \\
7 & $140.4, \mathrm{~d}$ & $141.0, \mathrm{~d}$ & $128.6, \mathrm{~d}$ & $121.2, \mathrm{~d}$ \\
8 & $72.6, \mathrm{~s}$ & $72.8, \mathrm{~s}$ & $133.1, \mathrm{~s}$ & $134.9, \mathrm{~s}$ \\
9 & $40.1, \mathrm{t}$ & $38.9, \mathrm{t}$ & $43.8, \mathrm{t}$ & $40.2, \mathrm{t}$ \\
10 & $24.0, \mathrm{t}$ & $23.8, \mathrm{t}$ & $69.1, \mathrm{~d}$ & $26.0, \mathrm{~d}$ \\
11 & $64.4, \mathrm{~d}$ & $63.6, \mathrm{~d}$ & $65.1, \mathrm{~d}$ & $62.1, \mathrm{~d}$ \\
12 & $62.4, \mathrm{~s}$ & $61.4, \mathrm{~s}$ & $62.4, \mathrm{~s}$ & $61.2, \mathrm{~s}$ \\
13 & $41.5, \mathrm{t}$ & $42.0, \mathrm{t}$ & $39.2, \mathrm{t}$ & $38.0, \mathrm{t}$ \\
14 & $24.6, \mathrm{t}$ & $25.3, \mathrm{t}$ & $24.7, \mathrm{t}$ & $24.5, \mathrm{t}$ \\
15 & $73.8, \mathrm{~s}$ & $73.8, \mathrm{~s}$ & $73.4, \mathrm{~s}$ & $73.4, \mathrm{~s}$ \\
16 & $29.2, \mathrm{q}$ & $29.3, \mathrm{q}$ & $29.7, \mathrm{q}$ & $29.7, \mathrm{q}$ \\
17 & $29.2, \mathrm{q}$ & $29.7, \mathrm{q}$ & $29.7, \mathrm{q}$ & $29.7, \mathrm{q}$ \\
18 & $18.5, \mathrm{q}$ & $18.5, \mathrm{q}$ & $18.5, \mathrm{q}$ & $18.0, \mathrm{q}$ \\
19 & $28.8, \mathrm{q}$ & $31.3, \mathrm{q}$ & $17.9, \mathrm{q}$ & $14.7, \mathrm{q}$ \\
20 & $15.8, \mathrm{q}$ & $15.7, \mathrm{q}$ & $18.0, \mathrm{q}$ & $16.1, \mathrm{q}$ \\
\hline & & & &
\end{tabular}

${ }^{a}$ Bruker-DRX-500 spectrometer $(125 \mathrm{MHz})$ in $\mathrm{CDCl}_{3}$; chemical shifts (ppm) referred to $\mathrm{CHCl}_{3}\left(\delta_{\mathrm{C}} 77.0\right)$; assignments were deduced from analysis of $1 \mathrm{D}$ and $2 \mathrm{D}$ spectra

b Data reported in the literature [19]
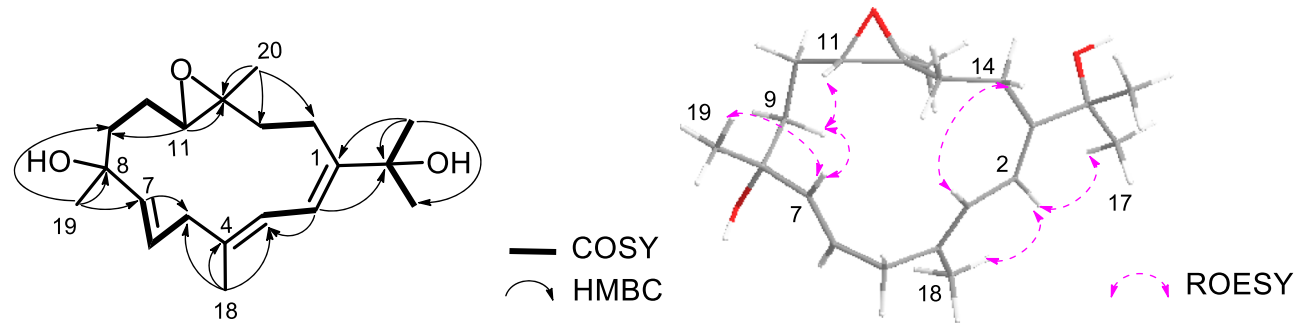

$\frown$ HMBC

Fig. 1 Key COSY, HMBC and ROESY correlations for compound 1

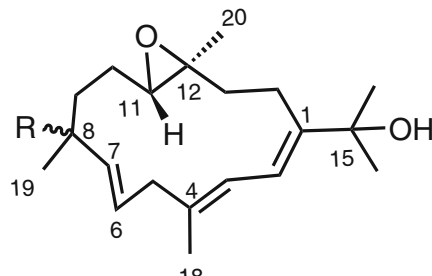

$1 \mathrm{R}=8 \alpha-\mathrm{OH}$

$2 \mathrm{R}=8 \beta-\mathrm{OH}$

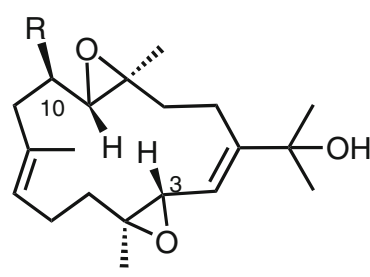

$3 \mathrm{R}=\mathrm{OH}$

$5 \mathrm{R}=\mathrm{H}$

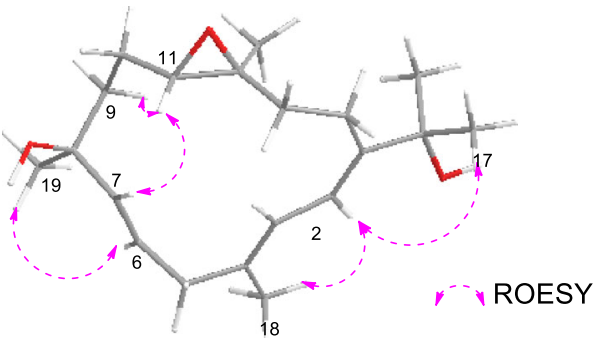

Fig. 3 Key ROESY correlations for compound 2

(150-200 mesh, Merck) and Sephadex LH-20 (Amersham Biosciences) were used for column chromatography. Semipreparative HPLC (Agilent 1100 series liquid chromatography using a VWDG1314A detector at $210 \mathrm{~nm}$ and a semi-preparative ODS-HG-5 [5 $\mu \mathrm{m}, 10 \mathrm{~mm} \quad$ (i.d.) $\times$ $25 \mathrm{~cm}$ ] column was also employed. Pre-coated silica gel $\mathrm{GF}_{254}$ plates (Qing Dao Hai Yang Chemical Group Co. Ltd. Qingdao, People's Republic of China) were used for analytical thin-layer chromatography (TLC). All solvents used were of analytical grade (Shanghai Chemical Reagents Company, Ltd.).

\subsection{Animal Material}

The soft corals $S$. trocheliophorum were collected by scuba at Yalong Bay, Hainan Province, China, in February 26,

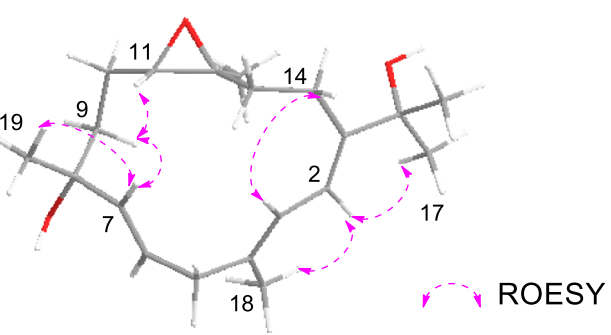

Fig. 2 Chemical structures of compounds 1-5 

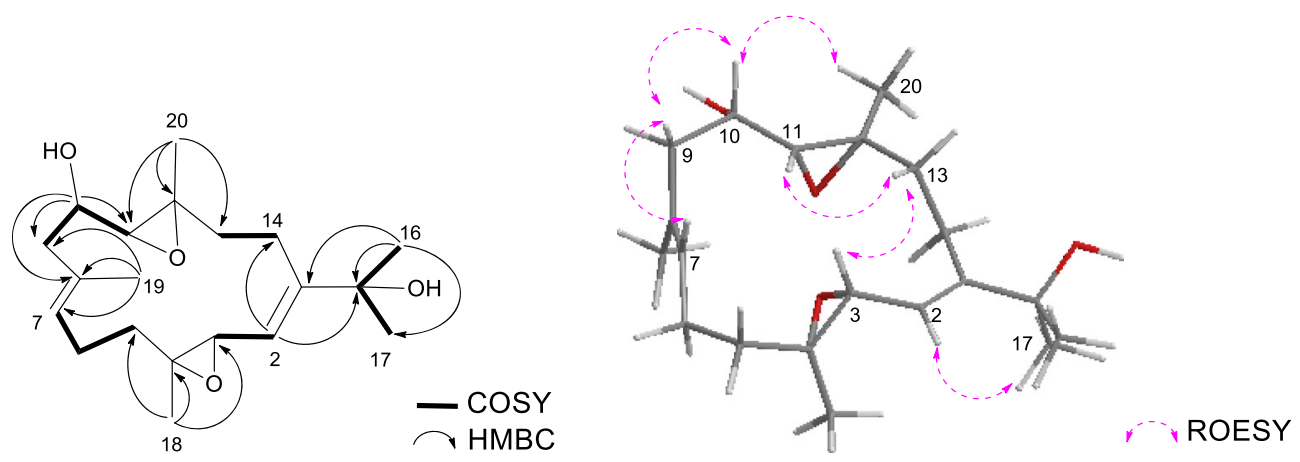

Fig. 4 Key COSY, HMBC and ROESY correlations for compound $\mathbf{3}$

2006 , at a depth of -15 to $-20 \mathrm{~m}$, and identified by Professor R.-L. Zhou of South China Sea Institute of Oceanology, Chinese Academy of Sciences. The voucher sample is deposited at the Shanghai Institute of Materia Medica, CAS, under registration No. YAL-4.

\subsection{Extraction and Isolation}

The lyophilized bodies of $S$. trocheliophorum (400 g, dry weight) were minced into pieces and exhaustively extracted with $\mathrm{Me}_{2} \mathrm{CO}$ at room temperature $(3 \times 1 \mathrm{~L})$. The solvent-free $\mathrm{Me}_{2} \mathrm{CO}$ extract was partitioned between $\mathrm{Et}_{2} \mathrm{O}$ and $\mathrm{H}_{2} \mathrm{O}$. The organic phase was evaporated under reduced pressure to give a dark brown residue $(10 \mathrm{~g})$, which was subjected to silica gel column chromatography $(\mathrm{CC})$ and eluted with petroleum ether (PE) in $\mathrm{Me}_{2} \mathrm{CO}(0-100 \%$, gradient) to yield 14 fractions (A-M).

Fraction D was chromatographed over silica gel (PE/ $\left.\mathrm{Et}_{2} \mathrm{O}, 1: 1\right)$ to give pure $4(32.1 \mathrm{mg})$. Fraction $\mathrm{F}$ was subjected to Sephadex LH-20 CC $\left(\mathrm{PE} / \mathrm{CH}_{2} \mathrm{Cl}_{2} / \mathrm{MeOH}, 2: 1: 1\right)$, followed by repeated silica gel $\mathrm{CC}\left(\mathrm{PE} / \mathrm{CH}_{2} \mathrm{Cl}_{2}, 20: 1\right)$ to yield 6 sub-fractions (F1-F6). F2 gave compound 5 $(2.3 \mathrm{mg})$ after silica gel $\mathrm{CC}\left(\mathrm{PE} / \mathrm{CH}_{2} \mathrm{Cl}_{2}, 10: 1\right)$. Fraction $\mathrm{G}$ was chromatographed over Sephadex LH-20 $\left(\mathrm{CHCl}_{3} /\right.$ $\mathrm{MeOH}, 1: 1)$, followed by $\mathrm{ODS}\left(\mathrm{MeOH} / \mathrm{H}_{2} \mathrm{O}, 50: 50-90: 10\right)$ to yield 10 sub-fractions (G1-G10). After purification by RP-HPLC $\left(\mathrm{MeOH} / \mathrm{H}_{2} \mathrm{O}, 88: 12,2.0 \mathrm{~mL} / \mathrm{min}\right)$, G5 yielded pure $1\left(2.4 \mathrm{mg}, t_{\mathrm{R}} 6.3 \mathrm{~min}\right)$. Fraction $\mathrm{H}$ gave compound $\mathbf{3}$ $\left(2.3 \mathrm{mg}, t_{\mathrm{R}} 12.5 \mathrm{~min}\right)$ after Sephadex LH-20 CC (PE/ $\left.\mathrm{CHCl}_{3} / \mathrm{MeOH}, \quad 2: 1: 1\right), \quad \mathrm{CC}$ on $\mathrm{ODS}\left(\mathrm{MeOH} / \mathrm{H}_{2} \mathrm{O}\right.$, 45:55-90:10) and RP-HPLC (MeOH/ $\mathrm{H}_{2} \mathrm{O}, 73: 27,2.0 \mathrm{~mL} /$ min). Fraction I was subjected to Sephadex LH-20 CC (PE/ $\mathrm{CHCl}_{3} / \mathrm{MeOH}, 2: 1: 1$ ) to give five sub-fractions (I1-I5). Fraction I4 was first split by $\mathrm{CC}$ on ODS $\left(\mathrm{MeOH} / \mathrm{H}_{2} \mathrm{O}\right.$, 50:50-90:10) and then purified by silica gel $\left(\mathrm{CHCl}_{3} /\right.$ $\mathrm{MeOH}, 50: 1)$ to afford pure $2(3.1 \mathrm{mg})$.

Sarcophytrol D (1): colorless oil; $[\alpha]+18.6$ (c 0.07, $\mathrm{MeOH}) ;{ }^{1} \mathrm{H}$ and ${ }^{13} \mathrm{C}$ NMR data, see Tables 1 and 2;
HRESIMS $\mathrm{m} / \mathrm{z} 343.2248\left[\mathrm{M}+\mathrm{Na}^{+}\right.$(calcd for $\mathrm{C}_{20} \mathrm{H}_{32}$ $\mathrm{O}_{3} \mathrm{Na}$, 343.2249).

Sarcophytrol E (2): colorless oil; $[\alpha]+48.6$ (c 0.10 , $\mathrm{MeOH}) ;{ }^{1} \mathrm{H}$ and ${ }^{13} \mathrm{C}$ NMR data, see Tables 1 and 2;

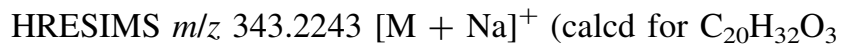
$\mathrm{Na}, 343.2249$ ).

Sarcophytrol F (3): colorless oil; $[\alpha]-12.7$ (c 0.20, $\mathrm{MeOH}) ;{ }^{1} \mathrm{H}$ and ${ }^{13} \mathrm{C}$ NMR data, see Tables 1 and 2 ; HRESIMS $m / z 359.2188[\mathrm{M}+\mathrm{Na}]^{+}$(calcd for $\mathrm{C}_{20} \mathrm{H}_{32} \mathrm{O}_{4}$ $\mathrm{Na}, 359.2188)$.

Acknowledgments This research work was financially supported by the National Marine "863" Projects (Nos. 2013AA092902 and 2012AA092105), the Natural Science Foundation of China (Nos. 81520108028, 81273430, 41506187, 41306130, 41476063), NSFC Shangdong Joint Fund for Marine Science Research Centers (Grant No. U1406402), SCTSM Project (No. 14431901100 and 15431901000), the SKLDR/SIMM Projects (SIMM1203ZZ-03 and 1501ZZ-03), and was partially funded by the EU 7th Framework Programme-IRSES Project (No. 246987).

\section{Compliance with Ethical Standards}

Conflict of Interest All authors declare no conflict of interest.

Open Access This article is distributed under the terms of the Creative Commons Attribution 4.0 International License (http:// creativecommons.org/licenses/by/4.0/), which permits unrestricted use, distribution, and reproduction in any medium, provided you give appropriate credit to the original author(s) and the source, provide a link to the Creative Commons license, and indicate if changes were made.

\section{References}

1. Z.D. Dinesen, Coral Reefs 1, 229-236 (1983)

2. K.E. Fabricius, Coral Reefs 16, 159-167 (1997)

3. B. Riegl, M.H. Schleyer, P.J. Cook, G.M. Branch, Bull. Mar. Sci. 56, 676-691 (1995)

4. B. Tursch, A. Tursch, Mar. Biol. 68, 321-332 (1982)

5. L.F. Liang, Y.W. Guo, Chem. Biodivers. 10, 2161-2196 (2013)

6. A.S.R. Anjaneyulu, G.V. Rao, J. Indian Chem. Soc. 74, 272-278 (1997) 
7. L.F. Liang, T. Kurtan, A. Mandi, L.G. Yao, J. Li, W. Zhang, Y.W. Guo, Org. Lett. 15, 274-277 (2013)

8. L.F. Liang, T. Kurtan, A. Mandi, L.G. Yao, J. Li, W. Zhang, Y.W. Guo, Eur. J. Org. Chem. 2014, 1841-1847 (2014)

9. W.T. Chen, L.G. Yao, X.W. Li, Y.W. Guo, Tetrahedron Lett. 56, 1348-1352 (2015)

10. X.H. Yan, M. Gavagnin, G. Cimino, Y.W. Guo, Tetrahedron Lett. 48, 5313-5316 (2007)

11. R. Jia, T. Kurtán, A. Mándi, X.H. Yan, W. Zhang, Y.W. Guo, J. Org. Chem. 78, 3113-3119 (2013)

12. L.F. Liang, L.F. Lan, O. Taglialatela-Scafati, Y.W. Guo, Tetrahedron 69, 7186-7381 (2013)

13. H. Dong, Y.L. Gou, R.M. Kini, H.X. Xu, S.X. Chen, S.L.M. Teo, P.P.H. But, Chem. Pharm. Bull. 48, 1087-1089 (2000)
14. W.T. Chen, H.L. Liu, L.G. Yao, Y.W. Guo, Steroids 92, 56-61 (2014)

15. Z.B. Cheng, Y.L. Deng, C.Q. Fan, Q.H. Han, S.L. Lin, G.H. Tang, H.B. Luo, S. Yin, J. Nat. Prod. 77, 1928-1936 (2014)

16. T. Řezanka, V.M. Dembitsky, Tetrahedron 57, 8743-8749 (2001)

17. L.F. Liang, L.X. Gao, J. Li, O. Taglialatela-Scafati, Y.W. Guo, Bioorg. Med. Chem. 21, 5076-5080 (2013)

18. C.Y. Duh, R.S. Hou, J. Nat. Prod. 59, 595-598 (1996)

19. R.S. Hou, C.Y. Duh, M.Y. Chiang, C.N. Lin, J. Nat. Prod. 58, 1126-1130 (1995)

20. J.C.H. Byon, A.B. Kusari, J. Kuseti, Mol. Cell. Biochem. 182, 101-108 (1998) 